\title{
Trading places, wide open spaces
}

\author{
Mary Mavroudis and April Yasamee
}

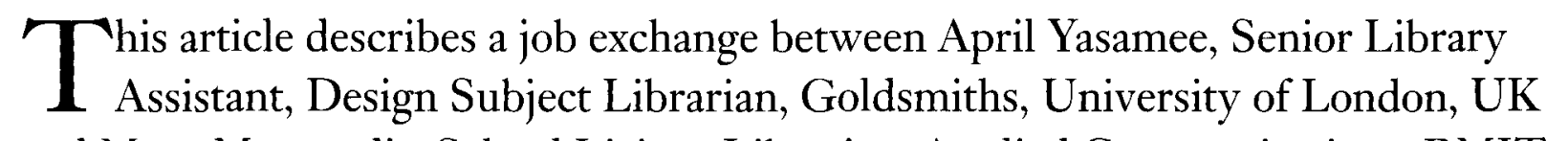
and Mary Mavroudis, School Liaison Librarian, Applied Communications, RMIT University, Melbourne, Australia. They exchanged jobs for three months between April and July 2007. April arrived in Melbourne just after the start of the academic year. Mary reached London at the beginning of the summer term and the exam period. The article takes the form of email correspondence between them, as they adapt to their new university libraries, noting the differences and similarities between the two institutions.

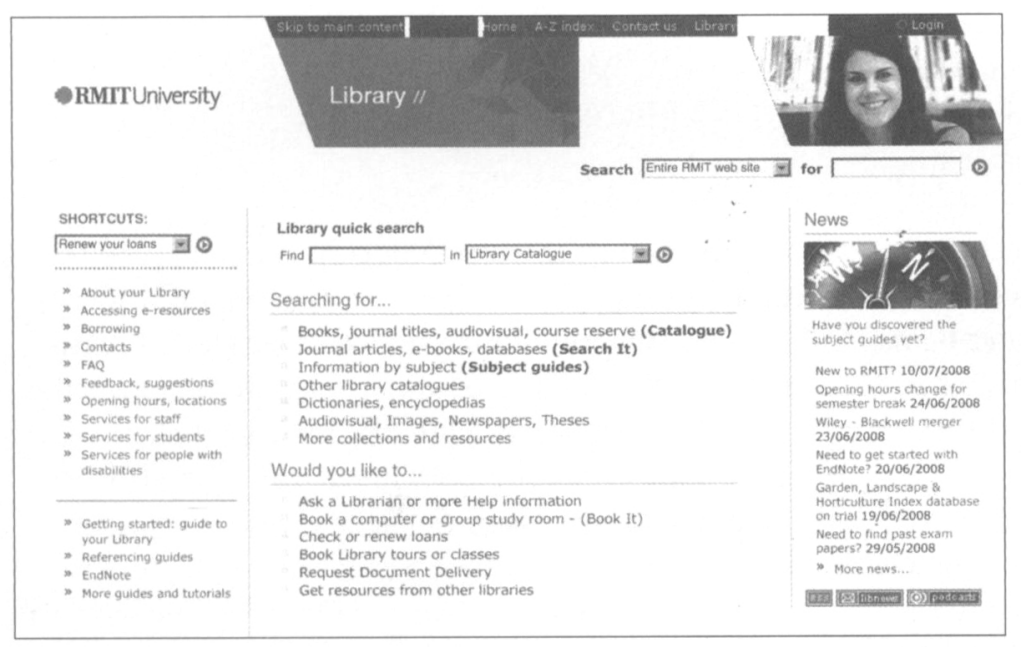

Dear Mary

I have arrived at RMIT and settled in. There is so much to take in at this busy start to the academic year. Your student numbers are about eight times higher than at Goldsmiths and the campus seems as big as the entire University of London. My exchange induction has included visits to the five site libraries around Melbourne. They are so individual and so far apart from one other: we drove out to Bundoora campus in the library staff car; it took over an hour to get there. The new buildings and gardens at Bundoora and Brunswick are beautiful, with lovely views from the reading rooms. I like your solutions to noise by having signposted silent areas with doors that the students can close.
Like you, I am working four days at Carlton Library and one day at the main Swanston library. I have got lost a couple of times at Swanston, searching for the Applied Communications collections, but the full-time shelvers have been very helpful in guiding me. They have explained how they manage the books for the School Liaison Librarians and I will certainly ask them if I want to do any weeding. They are so willing to help readers locate material and I like the large notices on the shelf ends, giving advice on finding books.

I am grateful to ARLIS/UK\& Ireland and the Design and Applied Arts Index Travel Award, who have helped fund me on this exchange. I'll be attending the Educause Australasia conference, here in Melbourne, thanks to Goldsmiths.

Best wishes, April

(Acting School Liaison Librarian, Applied Communications, RMIT)

Hi April

I've had a lovely first week wandering the lush, campus grounds and taking in the wonderful sounds emanating from the music and theatre buildings. 


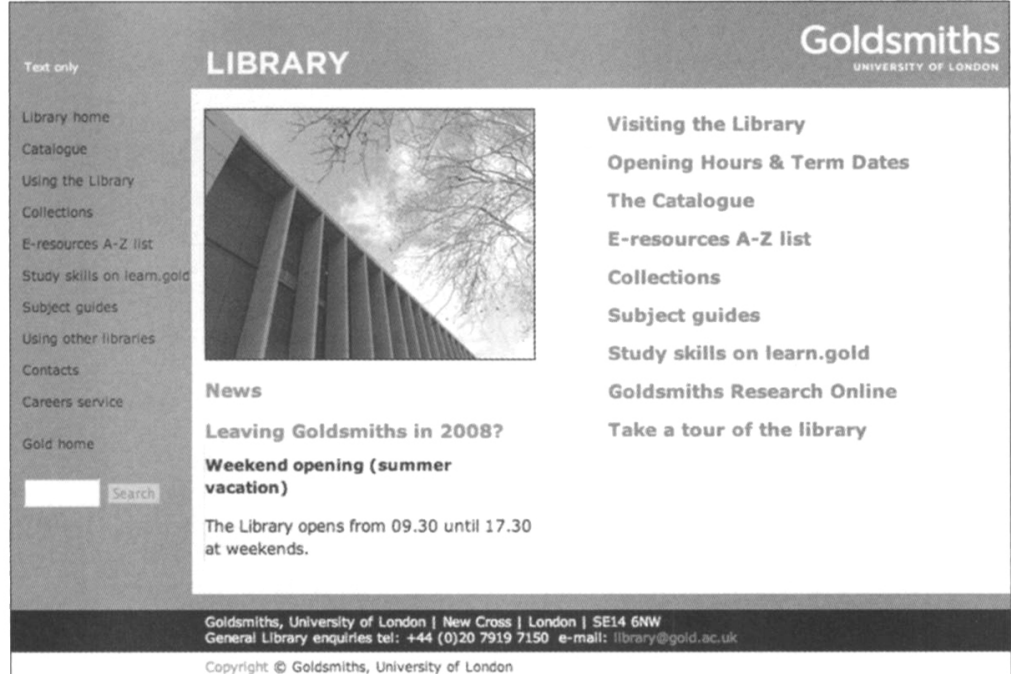

Coming from a large, interdisciplinary institution, the arts and humanities focus of Goldsmiths is just what I was hoping. As part of my induction I am familiarising myself with the library collection which is a little smaller than that at the RMIT Swanston campus. The art resources here are quite specialised compared to those at RMIT and I'm enjoying browsing through the exhibition catalogues and enormous art folios. I also like the layout of the library whereby all of arts and humanities resources are on one level and the education and social science resources on the other. How lovely also to have a reference desk on each level - everything the students need is within a short walk! I'm meeting with the Special Collections librarian next week to explore the incredible range of resources there; I am especially looking forward to seeing the Women's Art Library. I'm still getting used to swiping in and out of the security entrance to the library, often forgetting my card to the amusement of the porters. Also accepting money over the desk for fines is new for me, but it's so convenient for students and with the permanent security presence it seems safe enough.

\section{Cheers, Mary}

(Acting Senior Library Assistant, Design Subject Librarian, Goldsmiths)

\section{Dear Mary}

I am glad to see how similar our student cohort is: multi-cultural, Higher Education and Further Education, although you have a concentration of South East Asian students. I am impressed by your information leaflets in foreign languages, and RMIT Staff Development are offering Vietnamese name pronunciation classes. I suppose this stems from your new Vietnam campus? It surprises me that most of your students are in paid employment, even the undergraduates. I understand they are all funded via government Higher Education Credit loans, so they are under pressure to pay these back after graduation. I am finding it strange not seeing any ethnic groups in traditional dress in Melbourne; no shalwar kameez or veils, though there are plenty of students from the Indian subcontinent. Also, I haven't seen any local Aborigines. Where are they?

I am getting used to queries at the Enquiry desks now, but struggling with the responsibility for photocopier and printing problems. Thankfully your colleagues have helped out when students need help with binders and hole punching for their essays. I am finding that most of the Swanston Enquiry desk queries are directional, rather than subject linked, just as at Goldsmiths.

All the best, April

Hello April

Yes, the Goldsmiths student cohort is very multicultural with a large concentration of students from Europe, something we don't see all that often down in Australia. The undergraduates here use the physical collection heavily and manage their smaller allocation of ten borrowed items well. I've also noticed a strong postgraduate and research presence here which makes the reference desk a pleasure to work on. Though I am surprised by the low number of dedicated computers in the library for students to access electronic resources. It restricts the interaction between librarians and students solely to the reference desk, making it difficult for them to then re-apply the skills when they get to a computer. This is different to RMIT where librarians sit down with students at their PC or laptop to assist them. How are you finding the more roving, interactive model at RMIT? I've also found that there aren't many students from other institutions using the collection. It's a small specialist collection here - is this why reciprocal arrangement is for reference use only? But how fortunate for your students that they have extended hours of access to the collection, self check units and computers after the staffed service ends.

Cheers, Mary 
Hello Mary

Yes, laptop use is increasing at Goldsmiths, and we are not yet prepared for changes to the nature of enquiries that this may entail.

I have met the dedicated library Staff

Development Officer, and found your user education and staff development more open and flexible than ours, especially as sessions are repeated to accommodate working shift patterns, and staff can just book themselves into courses without having to ask their line managers first. You have a different concept of user education here at RMIT: it applies to all users, staff and students.

I like the glass-partitioned training rooms, within the library reading rooms. I think the visibility of student-led group work and library staff training reinforces the role of the library as a teaching base.

I appreciate how training lending and reference officers on databases encourages them to be familiar and confident with them and to promote them to students. This is refreshing and equitable: I have watched reference librarians leading generic eresource training sessions, like Google searching.

I have met quite a few staff who have temporarily exchanged roles between library departments, as well as those who have done secondments to other university libraries. I suppose these opportunities refresh and motivate staff?

I am enjoying living in Melbourne, but it is strange to be approaching winter in May!

\section{Cheers, April}

\section{Dear April}

Yes, RMIT library does have a Staff Development Officer, and I am surprised that there isn't one here. I've noticed that library assistants have few opportunities to work outside of their area or on special projects, which would assist them to gain the expertise required to successfully obtain positions when they arise.

This morning I assisted the art librarian with an information literacy session and witnessed the relevance of her art background when she instructed in topic exploration models of art research practice. It's not common for RMIT librarians to have a qualification in their liaison area but I certainly saw the benefit of it today. I've also met with one of your research students on a few occasions and found it comforting to know that I could apply my skills quite easily in a new subject area and country.

There have only been a handful of information literacy sessions conducted by the subject librarians whilst I've been here. I wonder if the model of liaising with a departmental representative makes it difficult to build relationships with other academic staff and to promote information literacy as a graduate capability.

It seems a greater shame given the subject expertise of the librarians and the research knowledge they have to offer.

Kind regards, Mary

\section{Hello Mary}

Historically, all Goldsmiths Subject Librarians liaise with one library representative from each academic department. They, in turn, liaise with other tutors and represent their interests to the library. It can be an inconsistent arrangement, depending on the academic department.

It's been a week of IT problems here, as the college server went down. I made telephone appointments with the IT technicians about the login problems I mentioned: they've been quick to visit. I hope you haven't had to deal with our OPACS going down or working 'off line' on the issue desk, yet.

Best wishes, April

\section{Dear April}

No, thankfully all systems have remained stable here! I've been liaising with the library representative from the Design department about how to best commit the remainder of the book budget. It's a small amount of money compared to what I'm used to which makes it all the more important to have him involved. I also attended the Library User Group meeting in the historic New Cross Town Hall. Here I met all of the other departmental library representatives.

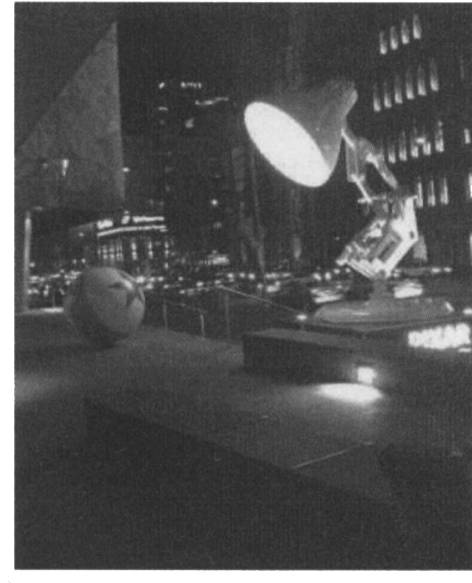

Pixar animation film festival, Australian Centre for the Moving Image, Federation square, Melbourne. (C) April Yasamee. 
The liaison model is quite different to that at RMIT where the librarians attend the department's staff meetings and make the majority of new purchase selections themselves, with staff and students able to make suggestions. I'm still undecided on the practice of subject librarians classifying and cataloguing new books in their area. On the one hand I've seen that it makes for an accurately organised collection, but on the other hand it leaves less time for outreach and liaison with the department.

All the best, Mary

\section{Hi Mary}

I have had a week of academic departmental meetings, all of which I was invited to. I didn't have to ask! Academic staff at RMIT are friendly and direct about what they expect from the library. By the way, I have been asked to sign off a new course proposal, for academic liaison. I am meeting the course convener next week, and am looking forward to being involved in a new academic course from the outset.

I have had a few individual research consultations with students too, via the School Liaison Librarians appointments system.

It is interesting to see how the School Liaison Librarians take responsibility for subject areas on a rotational basis. I understand they will eventually be integrated with teaching staff in the faculties, placing their research support roles closer to the academic departments.

School Liaison Librarians have been complaining at meetings of increasing administration work, so I suppose this transition is full of inconsistencies at present.

I am surprised the School Liaison Librarians don't have direct online ordering to your suppliers. Your Reference Librarians have been doing the bulk of the book orders for me from the comparatively huge book budgets. It is a joy not to be constrained by a small book fund!

I have been completing paper order requests then passing them to the Acquisitions department to approve and order. There's quite a backlog of orders, and it's difficult to trace the progress of orders. Who should I ask first?

I have noticed School Liaison Librarians tend not to physically manage your department collections; this is rather by proxy, through the Acquisitions department, lending and reference officers, and the shelvers.

Your recent restructuring seems to have created an extra management level now that you are managed by Portfolio Liaison Managers. Does this distance you from the decision making? I am interested as I'll be returning to a restructuring period at Goldsmiths.

I am wearing my winter coat and gloves in this foggy June weather. I expect you are in T-shirts and sandals in London.

Cheers, April

\section{Dear April}

We've had lovely 24-degree days this week and most people are enjoying the sun in shorts and t-shirts. Being used to really hot summers however I'm not quite ready to let go of my jacket just yet.

I followed up on a couple of the ARLIS member libraries you suggested I visit. I met with the Visual Art Librarian at University College last week and had a great time exploring this unique library, with its book collections lining the corridors and small nooks used as reading rooms. The librarian mentioned that the library has been used as a film set on occasion - it's so wonderfully historic and traditional I can see why. They have their own classification system however so I was surprised to learn that Dewey is not the standard for all libraries in the UK. Also I am thrilled to relay that RMIT and Goldsmiths are jointly supporting my attendance at the i3 information literacy conference in Scotland, which I am very much looking forward to.

\section{All the best, Mary}

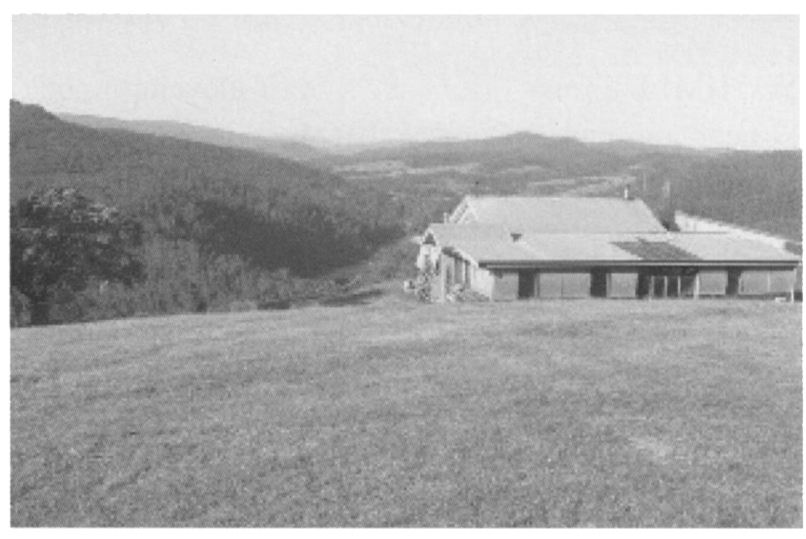

East Gippsland landscape.

(C) Kate Mottram.

\section{Hi Mary}

You seem to have less of a staff turnover here; I suppose it's the Australian employment conditions that help retain library staff. Long Service Leave 
sounds great, giving you three months paid leave and a job to return to.

I am finding the library staff structure more complicated than at Goldsmiths. You have a multiplicity of staff grades, after your restructuring two years ago. I have been listening to staff comments during the ongoing review, including some dissatisfaction over implementation. I understand there is some confusion over the responsibilities and workloads, and effects on staff development. I have to say these discussions are familiar to me, as Goldsmiths is commencing a similar restructuring.

Cheers mate, April

\section{Dear April}

Yes, the restructure was a shift from the liaison librarian working alone for a department to working in a liaison team and more aligned with the Portfolio (faculty). As you've noticed though there are still some things which need to be ironed out. I've been busy classifying new books and must say it's so refreshing to find that there isn't a cataloguing backlog here. I imagine it's due to the fact that orders are placed directly to suppliers by the subject librarians, freeing up the bibliographic services team to concentrate on processing books.

I also see the benefit of having a separate IT unit adjoined to the library with its own helpdesk. It's just lovely to refer technical queries to the helpdesk there or the staffed photocopy centre, allowing us to concentrate on assisting students with research at the reference desks. Is this perhaps why the desks are only staffed by subject librarians and not library assistants as well?

I was initially surprised to see how heavily the numerous silent study areas were used here. RMIT had a refurbishment last summer and based on student feedback, many of our silent spaces gave way to collaborative and lounge areas which the students use heavily. I have been asked to be involved in a discussion about the future redesign of the library here and I hope to relay some of the experiences from the RMIT library redesign.

All the best, Mary

\section{Hi Mary}

Now we're approaching the end of our exchange I am reviewing my user education practices, and changing my approach. I am happy to cede more control of the sessions to the students, as it gives more productive results, and students are more engaged, and communicative.

As for my interest in the Learning Environment, it is really apparent how the library sites affect staff and students' behaviour. The Enquiry desk team are more accessible at those brightly coloured jelly-bean enquiry desks and the students appear more purposeful and receptive when they make research appointments with School Liaison Librarians. Your student-run silent areas, especially the lockable Post Graduate Only rooms, really promote peer-learning and remove the need for library staff to police the reading rooms.

Our libraries differ in physical size and budgets, but I have found communications issues are a common feature. I agree with you about the importance of having clear staff communication strategies. I do sympathise with you finding yourself repeating the same information to various Goldsmiths colleagues, even though they are working in close proximity to each other. My colleagues here have been very helpful but my impression has been one of a very informationintensive working environment. There is a plethora of access points to staff information: the intranets, web sites, newsletters, email, the library drive folders on multiple levels, paper guides. I have found navigating the various sites a bit patchy. However, your Library Marketing Officer has described how she places great emphasis on communication with all the library's stakeholders. I am impressed with her open approach of publicising promotional events to students as well as VIPs.

My experience at RMIT has made the value of clear communications strategies more apparent to me.

I am looking forward to taking some holiday and visiting the Northern Territory next week. It will be good to be in a hot climate, as it's pretty cold in Melbourne now. Have a good trip around Europe.

Cheers mate, April

\section{Dear April}

It's been exciting to be here at a time when the layout of the library is being reviewed, with plans to highlight the unique special collections, create more collaborative spaces and some more electronic resource access terminals. There is also a staff restructure in the works which will hopefully provide more opportunities for staff to extend their 
current skills. Our libraries differ in physical size and staff numbers but I have gained many things to take back with me to apply in my own practice or relay to management. I have found that communication between staff and management can be a lot more direct due to fewer levels of management and things can be approved quickly when needed. A good acquisitions management system whereby librarians can place and monitor their own orders streamlines not only our work processes but has flow-on effects to the bibliographic services team, reducing paperwork, duplication of efforts and backlogs. The extended hours of opening, with a security presence, is also something that RMIT is considering so it's been great to see this in practice and know how much students appreciate it. The opportunity to see first hand the relevance of a personal background in the liaison subject area has been invaluable. I am inclined to return to study when I get home and pursue this for my own professional subject development. But first, it's off to France and Italy for a few weeks of sightseeing, sun and fabulous food.

Kind regards,

Mary

\author{
April Yasamee \\ Subject Librarian Art, Visual Cultures, Design \\ Library Website Manager \\ The Library \\ Goldsmitbs, University of London \\ New Cross \\ London SE14 6 NW \\ $U K$ \\ Email:a.yasamee@gold.ac.uk
}

Mary Mavroudis

Scbool Liaison Librarian, Applied Communications

Swanston Library

RMIT University

360 Swanston Street

Melbourne

Victoria 3000

Australia

Email:mary.mavroudis@rmit.edu.au 